Article

\title{
Effect of Hexavalent Chromium [Cr(VI)] on Phytoremediation Potential and Biochemical Response of Hybrid Napier Grass with and without EDTA Application
}

\author{
Bhagat Kanwar Ram ${ }^{1,2}$, Ying Han ${ }^{1}$, Gang Yang ${ }^{1}$, Qin Ling ${ }^{3}$ and Faqin Dong ${ }^{3, *}$ \\ 1 School of Life Sciences and Engineering, Southwest University of Science and Technology, \\ Mianyang 621010, China; msdo_sindh@yahoo.com (B.K.R.); hanying@swust.edu.cn (Y.H.); \\ yanggang903@swust.edu.cn (G.Y.) \\ 2 Department of Energy and Environment, Faculty of Agricultural Engineering, Sindh Agriculture University, \\ Tandojam 70060, Pakistan \\ 3 School of Environment and Resources, Southwest University of Science and Technology, \\ Mianyang 621010, China; lingqinchn@163.com \\ * Correspondence: fqdong@swust.edu.cn
}

Received: 18 October 2019; Accepted: 13 November 2019; Published: 17 November 2019

\begin{abstract}
Hexavalent chromium [Cr(VI)] contamination has become an emergent concern in China. Previous field investigations have found that hybrid Napier grass is widely distributed in $\mathrm{Cr}(\mathrm{VI})$ contaminated areas. This study investigated the phytoremediation potential and biochemical response of hybrid Napier grass (Pennisetum americanus L. $\times$ Pennisetum purpureum Schumach) grown in soil contaminated with $\mathrm{Cr}(\mathrm{VI})\left(0,20,40\right.$, and $\left.60 \mathrm{mg} \mathrm{kg}^{-1}\right)$ with and without Ethylene diamine tetra acetic acid (EDTA) $(4 \mathrm{mM})$ application. The results indicated that root length, shoot height, dry weight, leaf area, chlorophyll, and photosystem II (PSII) parameters viz.; apparent electron transport rate (ETR), effective quantum yield of PSII (ФPSII), maximal PSII photochemical efficiency (Fv/Fm), potential activity of PSII ( $\mathrm{Fv} / \mathrm{Fo})$, photochemical quenching ( $\mathrm{qP})$, and non-photochemical quenching $(\mathrm{qN})$ decreased with the increasing $\mathrm{Cr}(\mathrm{VI})$ concentration. EDTA application further aggravated reduction of dry biomass and photosystem II. The concentration and the accumulation of $\mathrm{Cr}$ in shoot and root, and both the bioaccumulation factor (BAF) and transfer factor (TF) increased with increasing $\mathrm{Cr}(\mathrm{VI})$ concentrations and further enhanced with EDTA application. Though the $\mathrm{Cr}(\mathrm{VI})$ and Ethylene diamine tetra acetic acid (EDTA) stress reduced tolerance, but, even at highest $\mathrm{Cr}(\mathrm{VI})$ concentration, plant could exhibited strong resistance, as evidenced by increase in superoxide dismutase (SOD), peroxidase (POD), and catalase (CAT) activities. Hybrid Napier grass, due to its BAF $>1$ and a TF $<1$, would be applicable for $\mathrm{Cr}$ phytostabilization. Moreover, limiting metal transport to aerial parts of plant would prevent animal's ingestion, restrict soil mobility, and consequently reduce transmission across the food chain.
\end{abstract}

Keywords: hexavalent Cr; phytoremediation; hybrid napier; Pennisetum; EDTA

\section{Introduction}

Leather, printing and dyeing industries are very well developed in different parts of the world, including China, which mainly exist in the form of small and medium-sized enterprises. Large concentrations of hexavalent chromium $[\mathrm{Cr}(\mathrm{VI})]$ are discharged into the environment, which poses a great threat to the surrounding ecological environment due to the imperfection of production process and wastewater treatment process [1]. However, the natural, average, and background levels 
of $\mathrm{Cr}$ in soils vary greatly in different regions of the world, as shown in Table 1 [2]. The $\mathrm{Cr}(\mathrm{VI})$ occurs in strong oxidizing forms and it is very toxic to plant, animal, and human, because of its high solubility and mobility [3]. Ethylene diamine tetra acetic acid (EDTA) is one of the common chelating agents, which enhances metal uptake, increases its transport from roots to shoot, and alters the metal speciation and phytotoxicity [4-6]. EDTA can disturb the concentration balance of $\mathrm{Cr}(\mathrm{VI})$ in the liquid and solid phases of soil to form mobile compounds, which can be leached with water or absorbed by plants by chelating or coordinating some difficult-to-move $\mathrm{Cr}$ [7]. Some resistant plants can still grow and reproduce there despite the harsh environment around these $\mathrm{Cr}(\mathrm{VI})$ contaminated factories.

Table 1. Natural and average $\mathrm{Cr}$ concentration in soils of different regions of the world.

\begin{tabular}{cccc}
\hline Cr Concentration $\left(\mathbf{m g ~ k g}^{\mathbf{- 1}}\right)$ & Parameter & Region & Reference \\
\hline $50-600$ & Back ground concentration & - & Ma and Hooda [8] \\
$5-3000$ & Back ground concentration & India & Shanker et al. [9] \\
$2-60$ & Natural concentration & Turkey & Isıkl et al. [10] \\
$10-50$ & Natural concentration & - & Adriano [11] \\
100 & Average concentration & West Indies & Mandal and Voutchkov [12] \\
59.5 & Average concentration & Poland & Kabata-Pendias [13] \\
22 & Average concentration & Sweden & Eriksson [14] \\
58 & Average concentration & Japan & Takeda et al. [15] \\
54 & Average concentration & USA & Burt et al. [16] \\
94.8 & Average concentration & Finland & Salminen et al. [17] \\
\hline
\end{tabular}

Adapted from Shahid et al. [2].

Our previous field investigations have found that hybrid Napier grass (Pennisetum americanum L. $\times$ Pennisetum purpureum Schumach) widely distributed in the areas contaminated by different levels of $\mathrm{Cr}(\mathrm{VI})$, which indicated that the plant had strong resistance to $\mathrm{Cr}$ pollution, but its ability to absorb $\mathrm{Cr}$ was not clear. Besides, the information regarding the effects of different concentrations of $\mathrm{Cr}(\mathrm{VI})$ with and without EDTA application on the phytoremediation potential and physiological characteristics of hybrid Napier grass is lacking. Such information would be critical in the development of hybrid Napier grass as a phytoremediation plant in $\mathrm{Cr}$-contaminated areas. Previous studies indicated that $\mathrm{Cr}(\mathrm{VI})$ stress has a stimulating effect on the growth of most plant seedlings at low concentrations, whereas it has an inhibiting effect on plant at high concentrations [18-21]. A low concentration of $\mathrm{Cr}(\mathrm{VI})$ can increase the net photosynthetic rate and promote the growth of plants by enhancing the electron transfer activity of PSII. It can increase the proportion of pith and epidermis in roots and promote the growth of roots and root hairs [18]. Whereas, a high concentration of $\mathrm{Cr}(\mathrm{VI})$ hinders water transport, reduces transpiration, affects root uptake of mineral elements, and interferes with enzymatic reactions in plants, which results in plant dwarfing, leaf yellowing and shedding, and biomass reduction [19-23]. In addition, Bareen and Tahira [24] found that seven different cultivated plant species absorbed more $\mathrm{Cr}$ under EDTA application. Although the phytotoxicity and remediation potential under soil $\mathrm{Cr}(\mathrm{VI})$ stress has been investigated in many plant species, the Pennisetum species have been given less attention. Thus, it is crucial to understand the response of the native plants distributed at $\mathrm{Cr}$ contaminated area to develop potential $\mathrm{Cr}$ hyperaccumulator or $\mathrm{Cr}$-tolerant plants for remediating $\mathrm{Cr}$-contaminated soils or the rehabilitation of vegetation.

Pennisetum species belong to family Poaceae, which grow annually or perennially. There are about 140 species in the world, most of which are native to Africa. In China, they are mainly distributed in Northeast, North, East, Central South, and Southwest of China. Hybrid Napier grass is a triploid hybrid that is produced by crossing diploid Pennisetum americanus L. with tetraploid elephant grass (Pennisetum purpureum Schumach). Hybrid Napier grass species are more vigorous and resistant to unfavorable environment $[25,26]$; however, its mechanism of tolerance has not been fully understood. In addition, its tolerance and accumulation characteristics of heavy metals in polluted soils remain to be discovered. Therefore, the objectives of the present study were to evaluate the effect of $\mathrm{Cr}(\mathrm{VI})$ with and without 
EDTA application on the phytoremediation potential, growth performance, photosynthetic efficiency, and antioxidant enzyme activity in native hybrid Napier grass to develop potential $\mathrm{Cr}$ hyperaccumulator or Cr-tolerant plants for remediating Cr-contaminated soils or rehabilitation of vegetation.

\section{Results}

\subsection{Growth Characteristics of Hybrid Napier Grass}

The $\mathrm{Cr}(\mathrm{VI})$ treatment produced dose-dependent effects on plant growth in both non-EDTA treated plants (NET-plants) and EDTA treated plants (ET-plants) and the maximum effects were noticed at highest dose of chromium Cr60 $\left(60 \mathrm{mg} \mathrm{kg}^{-1}\right)$ in soil as compared with their corresponding controls (Cr0 i.e., $0 \mathrm{mg} \mathrm{kg}^{-1}$ of $\mathrm{Cr}(\mathrm{VI})$ in soil) (Figure $\left.1 \mathrm{a}-\mathrm{f}\right)$. Shoot height (SH), root length (RL), and leaf area (LA) were decreased $(p<0.005)$ by $28.89 \%, 31.95 \%$, and $42.82 \%$ in NET-plants and by $30.74 \%$, $41.79 \%$, and $47.78 \%$ in ET-plants, respectively, at Cr60 when compared with their corresponding controls (Figure 1a,b,e). Dry weights (DW) of shoot and root decreased $(p<0.005)$ by $53.33 \%$ and $29.58 \%$, respectively, in NET-plants and by $26.79 \%$ and $38.85 \%$, respectively, in ET-plants, at Cr60 when compared with their corresponding controls (Figure 1c,d).

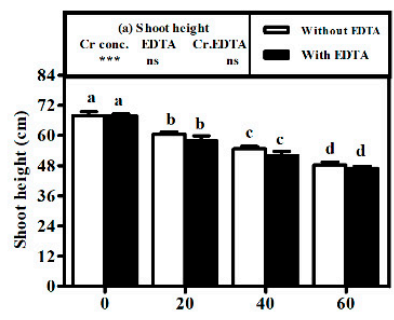

Soil Cr concentration ( $\mathrm{mg} \mathrm{kg}^{-1}$ )

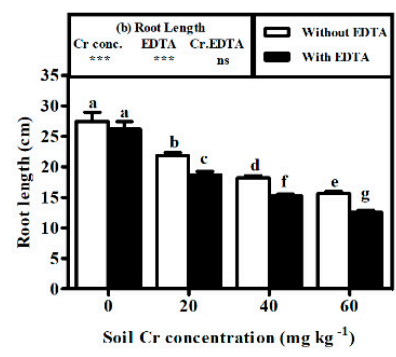

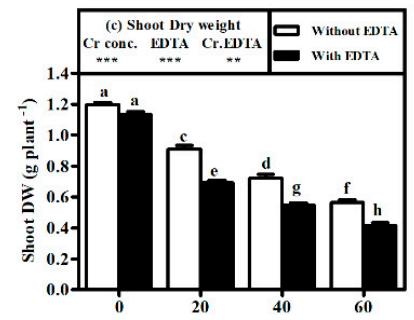

Soil Cr concentration (mg kg ${ }^{-1}$ )

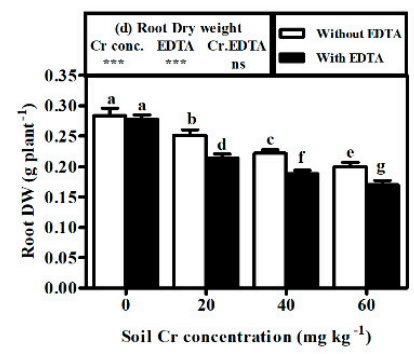

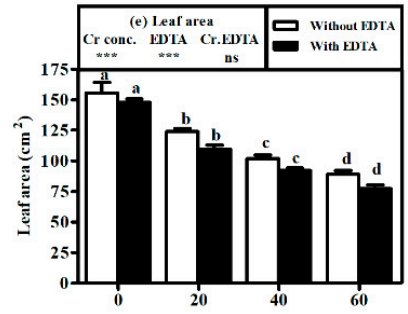

Soil Cr concentration ( $\mathrm{mg} \mathrm{kg}^{-1}$ )

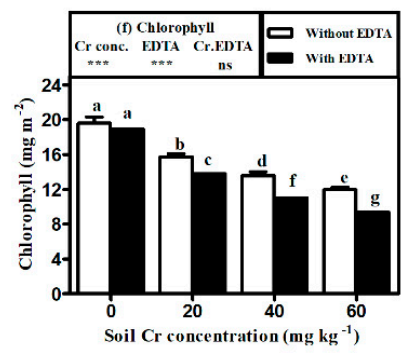

Figure 1. Influence of various $\mathrm{Cr}(\mathrm{VI})$ concentrations in soil on (a) shoot height, (b) root length, (c) shoot dry weight, (d) root dry weight, (e) leaf area, and (f) chlorophyll content of hybrid Napier grass with and without ethylene diamine tetra acetic acid (EDTA) application. Bars with dissimilar letters are significantly different at $p<0.05$ from Tukey's test. Values are means $\pm \mathrm{SE}, n=5$. ${ }^{* *} p<0.001$; *** $p \leq 0.001$. ns: non-significant, $\mathrm{Cr}$ conc.: soil $\mathrm{Cr}(\mathrm{VI})$ concentration effect; EDTA: EDTA effect and $\mathrm{Cr}$ conc. EDTA: $\mathrm{Cr}(\mathrm{VI})$ conc. $\times$ EDTA interaction effect.

Comparison between two treatments showed that the SH, RL, shoot DW, root DW, and LA decreased by $2.93 \%, 19.82 \%, 26.79 \%, 15 \%$, and $12.94 \%$ in ET-plants as compared with NET-plants at Cr60 (Figure 1a-e). However, the above measured parameters were statistically non-significant $(p>0.05)$ between the two groups, except for DW of root and shoot, which showed a significant decrease $(p<0.05)$ in ET-plants as compared with NET-plants.

\section{2. $\mathrm{Cr}$ Accumulation and Phytoremediation Potential}

The $\mathrm{Cr}$ concentration and accumulation in root and shoot of hybrid Napier grass increased with increasing $\mathrm{Cr}(\mathrm{VI})$ concentrations in soil (Table 2). Generally, the $\mathrm{Cr}$ concentration and accumulation 
was higher in the root than in shoot. The $\mathrm{Cr}$ concentration and accumulation increased by $34.73 \%$ and $6.94 \%$ in roots and by $230.29 \%$ and $103.81 \%$ in shoot of NET-plants, respectively, at Cr60 as compared with $\mathrm{Cr} 20$ ( $20 \mathrm{mg} \mathrm{kg}^{-1}$ of $\mathrm{Cr}(\mathrm{VI})$ in soil). The $\mathrm{Cr}$ concentration and accumulation increased by $99.86 \%$ and $58.89 \%$ in roots and by $234.7 \%$ and $101.64 \%$ in shoot of ET-plants, respectively, at Cr60 when compared with $\mathrm{Cr} 20$. EDTA application significantly increased $\mathrm{Cr}$ concentration and accumulation in shoot, whereas decreased their concentrations in roots (Table 2). The maximum increase in $\mathrm{Cr}$ concentration and accumulation occurred by $114.32 \%$ and $59.28 \%$, respectively, in shoot of ET-plants as compared with NET-plants at $\mathrm{Cr} 60$. Whereas the maximum decrease in $\mathrm{Cr}$ concentration and accumulation in roots was observed by $81.52 \%$ and $114.3 \%$, respectively, at $\mathrm{Cr} 40$ in ET-plants as compared with NET-plants.

Table 2. Influence of various $\mathrm{Cr}(\mathrm{VI})$ concentrations in soil on $\mathrm{Cr}$ concentration and $\mathrm{Cr}$ accumulation in root and shoot, and Transfer factor (TF) and Bioaccumulation factor (BAF) of hybrid Napier grass with and without EDTA application.

\begin{tabular}{|c|c|c|c|c|c|c|c|}
\hline \multirow{2}{*}{$\begin{array}{c}\text { Soil Cr(VI) } \\
\text { Conc. (mg } \\
\left.\mathrm{kg}^{-1}\right)\end{array}$} & & \multicolumn{2}{|c|}{ Cr Concentration (mg kg ${ }^{-1}$ ) } & \multicolumn{2}{|c|}{$\begin{array}{l}\text { Cr Accumulation ( } \mu \mathrm{g} \\
\text { Plant }^{-1} \text { ) }\end{array}$} & \multirow[t]{2}{*}{ TF } & \multirow[t]{2}{*}{ BAF } \\
\hline & & Root & Shoot & Root & Shoot & & \\
\hline \multirow[b]{2}{*}{0} & Without EDTA & $2.45 \pm 0.89 \mathrm{~g}$ & $1.48 \pm 0.45^{f}$ & $0.69 \pm 0.34 \mathrm{~g}$ & $1.77 \pm 0.6^{\mathrm{f}}$ & - & - \\
\hline & With EDTA & $1.22 \pm 0.02 \mathrm{~g}$ & $2.38 \pm 1.52^{f}$ & $0.34 \pm 0.08 \mathrm{~g}$ & $2.69 \pm 1.4^{\mathrm{f}}$ & - & - \\
\hline \multirow[b]{2}{*}{20} & Without EDTA & $374.6 \pm 2.4^{\mathrm{d}}$ & $22.2 \pm 1.41 \mathrm{~g}$ & $94.37 \pm 7.75^{c}$ & $20.29 \pm 1.6^{g}$ & $0.06 \pm 0.005^{\mathrm{e}}$ & $1.11 \pm 0.07^{\mathrm{f}}$ \\
\hline & With EDTA & $233.7 \pm 0.6^{f}$ & $46.97 \pm 3.15^{\mathrm{e}}$ & $50.01 \pm 1.55^{\mathrm{e}}$ & $32.66 \pm 2.8^{\mathrm{e}}$ & $0.2 \pm 0.014^{\mathrm{e}}$ & $2.35 \pm 0.16^{c}$ \\
\hline \multirow{2}{*}{40} & Without EDTA & $473.6 \pm 1.7^{b}$ & $64.6 \pm 0.84^{d}$ & $105 \pm 2.49^{a}$ & $46.66 \pm 1.9^{c}$ & $0.14 \pm 0.002 \mathrm{~g}$ & $1.61 \pm 0.02^{d}$ \\
\hline & With EDTA & $261 \pm 0.92^{\mathrm{e}}$ & $114.5 \pm 5.6^{\mathrm{b}}$ & $49.05 \pm 1.51^{\mathrm{f}}$ & $62.71 \pm 4.3^{b}$ & $0.44 \pm 0.022^{c}$ & $2.86 \pm 0.14^{\mathrm{a}}$ \\
\hline \multirow{2}{*}{60} & Without EDTA & $504.7 \pm 0.7^{\mathrm{a}}$ & $73.35 \pm 4.06^{c}$ & $101 \pm 3.44^{\mathrm{b}}$ & $41.4 \pm 2.65^{\mathrm{d}}$ & $0.15 \pm 0.008^{f}$ & $1.22 \pm 0.07^{\mathrm{e}}$ \\
\hline & With EDTA & $467 \pm 1.96^{\mathrm{c}}$ & $157.21 \pm 12^{\mathrm{a}}$ & $79.45 \pm 3.6^{\mathrm{d}}$ & $65.9 \pm 7.79^{a}$ & $0.34 \pm 0.03^{d}$ & $2.62 \pm 0.2^{b}$ \\
\hline \multicolumn{8}{|c|}{ Statistical Effect } \\
\hline \multicolumn{2}{|c|}{$\mathrm{Cr}(\mathrm{VI})$ conc. } & $* * *$ & $* * *$ & $* * *$ & $* * *$ & $* * *$ & $* * *$ \\
\hline \multicolumn{2}{|c|}{ EDTA } & $* * *$ & $* * *$ & $* * *$ & $* * *$ & $* * *$ & $* * *$ \\
\hline \multicolumn{2}{|c|}{$\mathrm{Cr}(\mathrm{VI})$ conc. $\times$ EDTA } & $* * *$ & $* * *$ & $* * *$ & ns & $* * *$ & $* * *$ \\
\hline
\end{tabular}

Values (means $\pm \mathrm{SE}, n=5$ ) with dissimilar letters show significant difference at $p<0.05$ from Tukey's test, between different $\mathrm{Cr}(\mathrm{VI})$ doses within each treatment, and between two treatments (with and without EDTA), respectively, in the columns. ${ }^{* * *} p \leq 0.001$. ns: non-significant, $\mathrm{Cr}$ conc.: soil $\mathrm{Cr}(\mathrm{VI})$ concentration effect; EDTA: EDTA effect and Cr conc. EDTA: $\mathrm{Cr}(\mathrm{VI})$ conc. $\times$ EDTA interaction effect.

The bioaccumulation factor (BAF) and the transfer factor (TF) were measured to estimate the transfer of $\mathrm{Cr}$ from treated soil to the plant to assess the phytoremediation potential of plant (Table 2). The BAF values were $>1$ and further increased with increasing $\mathrm{Cr}(\mathrm{VI})$ concentrations in soil. The maximum BAF values were 1.61 and 2.86 in NET-plants and ET-plants at Cr40 $\left(40 \mathrm{mg} \mathrm{kg}^{-1}\right.$ of $\mathrm{Cr}(\mathrm{VI})$ in soil), respectively. The EDTA application increased the BAF by $114.75 \%$ at Cr60 in ET-plants as compared with NET-plants. Though the TF increased with increasing $\mathrm{Cr}(\mathrm{VI})$ concentration in soil, the overall values for TF were $<1$. The maximum values for TF were 0.15 at $\mathrm{Cr} 60$ in NET-plants and 0.44 at $\mathrm{Cr} 40$ in ET-plants, respectively. Moreover, the EDTA application increased $\mathrm{Cr}$ transport from root to shoot and the maximum increase in TF was observed by $233.33 \%$ at Cr20 in ET-plants as compared with NET-plants.

\subsection{Tolerance Index}

The $\mathrm{Cr}(\mathrm{VI})$ stress reduced the tolerance indices (TI) of hybrid Napier grass with increasing $\mathrm{Cr}(\mathrm{VI})$ concentrations in soil (Table 3). A maximum decrease in TI of root and shoot was observed by $29 \%$ and 53\% in NET-plants and by $39 \%$ and $63 \%$ in ET-plants at Cr60, respectively, when compared with their corresponding controls $(\mathrm{TI}=1)$. The EDTA application caused a further decrease in $\mathrm{TI}$ and the reduction was $27 \%$ and $16.4 \%$ higher in the shoot and root of ET-plants as compared with NET-plants. Moreover, the $\mathrm{Cr}(\mathrm{VI})$ toxicity was higher in the shoot than in root of hybrid Napier grass. 
Table 3. Effects of various $\mathrm{Cr}(\mathrm{VI})$ concentrations in soil on tolerance indices (TI) of root and shoot of hybrid Napier grass with and without EDTA application.

\begin{tabular}{|c|c|c|c|c|}
\hline \multirow{2}{*}{$\begin{array}{l}\text { Soil Cr(VI) Conc. } \\
\left(\mathrm{mg} \mathrm{kg}^{-1}\right)\end{array}$} & \multicolumn{2}{|c|}{ Shoot TI } & \multicolumn{2}{|c|}{ Root TI } \\
\hline & Without EDTA & With EDTA & Without EDTA & With EDTA \\
\hline 0 & 1 & 1 & 1 & 1 \\
\hline 20 & $0.76 \pm 0.024^{a}$ & $0.61 \pm 0.021^{b}$ & $0.89 \pm 0.047^{a}$ & $0.77 \pm 0.02^{b}$ \\
\hline 40 & $0.6 \pm 0.022^{c}$ & $0.48 \pm 0.02^{\mathrm{d}}$ & $0.79 \pm 0.054^{b, c}$ & $0.68 \pm 0.03^{c}$ \\
\hline 60 & $0.47 \pm 0.017^{\mathrm{e}}$ & $0.37 \pm 0.022^{f}$ & $0.71 \pm 0.02^{\mathrm{c}, \mathrm{d}}$ & $0.61 \pm 0.026^{d}$ \\
\hline \multicolumn{5}{|l|}{ Statistical Effect } \\
\hline Cr conc. & \multicolumn{2}{|c|}{$* * *$} & \multicolumn{2}{|c|}{$* * *$} \\
\hline EDTA & \multicolumn{2}{|c|}{$* * *$} & \multicolumn{2}{|c|}{$* * *$} \\
\hline $\mathrm{Cr} \times \mathrm{EDTA}$ & \multicolumn{2}{|c|}{ ns } & \multicolumn{2}{|c|}{$* *$} \\
\hline
\end{tabular}

Values (means \pm SE, $n=5$ ) with dissimilar letters show significant difference at $p<0.05$ from Tukey's test, between different $\mathrm{Cr}(\mathrm{VI})$ doses within each treatment, and between two treatments (with and without EDTA), respectively, in the columns. ${ }^{* *} p<0.001 ;{ }^{* * *} p \leq 0.001$. ns: non-significant, $\mathrm{Cr}$ conc.: soil $\mathrm{Cr}(\mathrm{VI})$ concentration effect; EDTA: EDTA effect and $\mathrm{Cr}$ conc. EDTA: $\mathrm{Cr}(\mathrm{VI})$ conc. $\times$ EDTA interaction effect.

\subsection{Chlorophyll Content and Photosynthetic Efficiency}

The $\mathrm{Cr}(\mathrm{VI})$ contamination in soil caused a concentration dependent reduction in the leaf chlorophyll content of hybrid Napier grass (Figure 1f) and the maximum decrease $(p<0.001)$ was observed by $38.98 \%$ in NET-plants and by $50.68 \%$ in ET-plants at Cr60 when compared with their corresponding controls. However, the reduction of chlorophyll content was further escalated with EDTA application in $\mathrm{Cr}(\mathrm{VI})$ contaminated soil. The EDTA application led to a reduction in chlorophyll content by $21.74 \%$ at Cr60 in ET-plants when compared with NET-plants.

Photosynthetic capacity of plant, such as maximum quantum yield (Fv/Fm), efficiency of water-splitting complex (Fv/Fo), effective photochemical quantum yield of PSII (ФPSII), electron transport (ETR), photochemical quenching (qP), and non-photochemical fluorescence quenching (qN), was measured (Figure 2a-f). In NET-plants, $\mathrm{Cr}(\mathrm{VI})$ stress caused slight reduction $(p<0.05)$ by $7 \%, 5.2 \%$ and $2.8 \%$ in $\mathrm{Fv} / \mathrm{Fm}$, $\Phi P S I I$ and $\mathrm{qP}$ at $\mathrm{Cr} 60$, respectively, as compared with control. Whereas, ETR, Fv/Fo, and $\mathrm{qN}$ were moderately affected by $\mathrm{Cr}(\mathrm{VI})$ stress. ETR and Fv/Fo were decreased $(p<0.05)$ by $15.6 \%$ and $20 \%$ and $\mathrm{qN}$ increased by $43.9 \%$, respectively, at Cr60 when compared with control. Moreover, no significant difference $(p>0.05)$ was observed among various $\mathrm{Cr}(\mathrm{VI})$ doses on the photosynthetic efficiency of NET-plants.

On the other hand, $\mathrm{Cr}(\mathrm{VI})$ produced dose-dependent effects on PSII efficiency in ET-plants, except for $\mathrm{qP}$, which showed no significant difference $(p>0.05)$ among the treatments. The maximum decrease $(p<0.05)$ was observed by $31.6 \%, 134 \%, 35 \%$, and 57.5\% in Fv/Fm, Fv/Fo, ФPSII, and ETR at Cr60, respectively, as compared with control. Nevertheless, $\mathrm{qN}$ increased by $314 \%$ at $\mathrm{Cr} 60$ when compared with control. The addition of EDTA along with $\mathrm{Cr}(\mathrm{VI})$ in soil fortified the toxic effects on photosynthetic efficiency in plant. The EDTA application caused a further decrease in Fv/Fm, Fv/Fo, ФPSII, and ETR by $19.1 \%, 50.4 \%, 23.1 \%$, and $30.3 \%$, and increase in qN by $59.8 \%$ at Cr60, respectively, in ET-plants as compared with NET-plants.

\subsection{Nitrogen (N) and Sulfur (S) Status in Hybrid Napier Grass}

Irrespective of dosage, $\mathrm{Cr}(\mathrm{VI})$ stress caused significant $(p<0.05)$ alterations in contents $(\%)$ of nitrogen $(\mathrm{N})$ and sulfur $(\mathrm{S})$ in root and shoot of plant (Figure $3 \mathrm{a}-\mathrm{d}$ ). The $\mathrm{N}$ content increased by $55.45 \%$ and $54.2 \%$ in root and shoot of NET-plants at $\mathrm{Cr} 40$ and Cr20, respectively, whereas the S content decreased by $26.71 \%$ and $93.6 \%$ in root and shoot of NET-plants at $\mathrm{Cr} 20$ and $\mathrm{Cr} 40$, respectively, when compared to control. In ET-plants, maximum increase in $\mathrm{N}$ content was observed by $47.7 \%$ in root at Cr60 and by $39.75 \%$ in shoot at $\mathrm{Cr} 20$, respectively, as compared with the control. The $\mathrm{S}$ content in root first decreased by $17.6 \%$ at $\mathrm{Cr} 20$ and then maximum increased by $81.8 \%$ at $\mathrm{Cr} 60$ when compared 
with the control. Nevertheless, the $\mathrm{S}$ content in shoot decreased at all $\mathrm{Cr}(\mathrm{VI})$ concentrations and the maximum decrease was observed by $82.6 \%$ at $\mathrm{Cr} 20$ as compared with control.

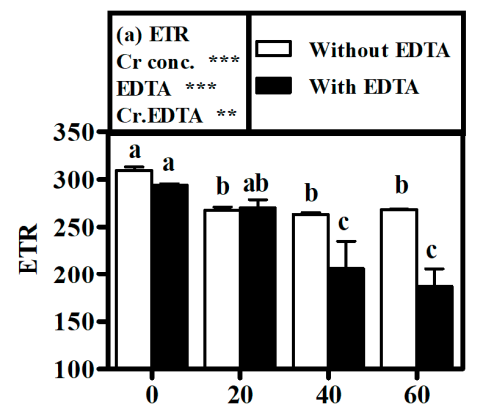

Soil Cr concentration $\left(\mathrm{mg} \mathrm{kg}^{-1}\right)$

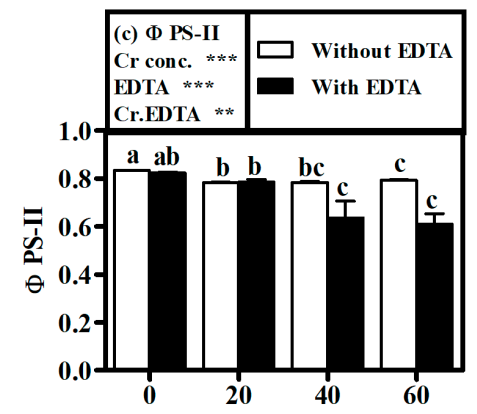

Soil $\mathrm{Cr}$ concentration ( $\mathrm{mg} \mathrm{kg}^{-1}$ )

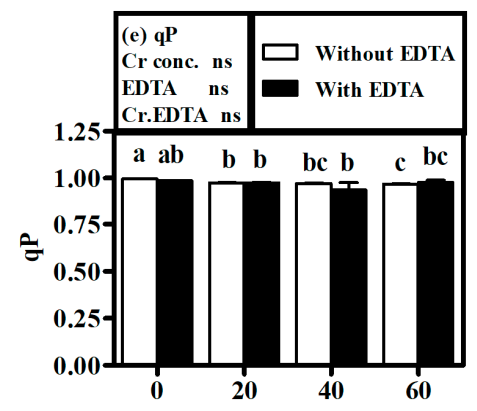

Soil $\mathrm{Cr}$ concentration $\left(\mathrm{mg} \mathrm{kg}^{-1}\right)$

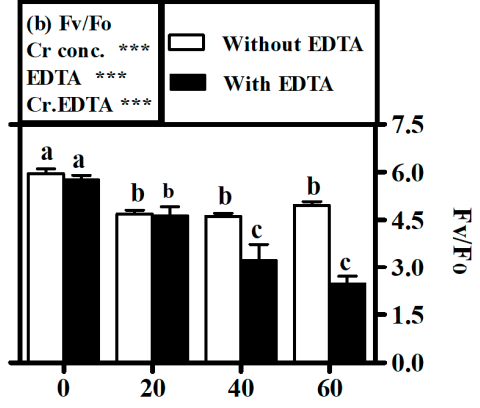

Soil $\mathrm{Cr}$ concentration $\left(\mathrm{mg} \mathrm{kg}^{-1}\right)$

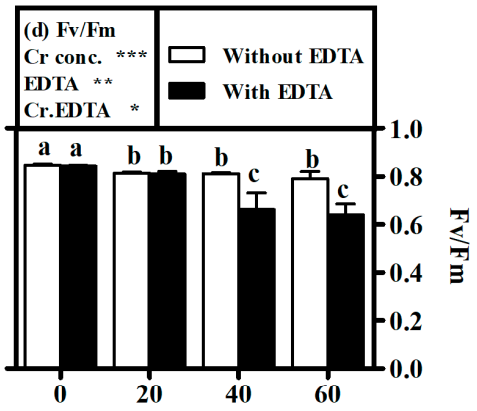

Soil Cr concentration ( $\mathrm{mg} \mathrm{kg}^{-1}$ )

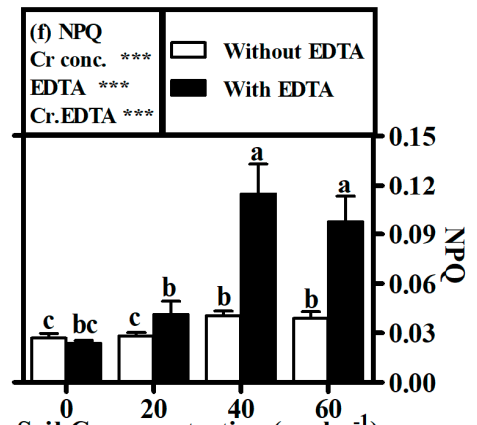

Soil Cr concentration (mg kg-1)

Figure 2. Influence of various $\mathrm{Cr}(\mathrm{VI})$ concentrations in soil on chlorophyll- $\alpha$ fluorescence parameters: (a) apparent electron transport rate (ETR), (b) potential activity of PSII (Fv/Fo), (c) effective quantum yield of PSII (ФPSII) (d) maximal PSII photochemical efficiency (Fv/Fm) (e) photochemical quenching $(\mathrm{qP})$ and (f) non-photochemical quenching (NPQ or $\mathrm{qN}$ ) of hybrid Napier grass with and without EDTA application. Bars with dissimilar letters are significantly different at $p<0.05$ from Tukey's test. Values are means $\pm \mathrm{SE}, n=5$. ${ }^{*} p<0.05 ;{ }^{* *} p<0.001 ;{ }^{* * *} p \leq 0.001$. ns: non-significant, Cr conc.: soil Cr(VI) concentration effect; EDTA: EDTA effect and $\mathrm{Cr}$ conc. EDTA: $\mathrm{Cr}(\mathrm{VI})$ conc. $\times$ EDTA interaction effect.

EDTA application showed a variable response to $\mathrm{N}$ and $\mathrm{S}$ contents in the root. The $\mathrm{N}$ content in root increased by approximately $18 \%$ at $\mathrm{Cr} 20$ and $\mathrm{Cr} 60$, respectively, and decreased by $9.4 \%$ at $\mathrm{Cr} 40$ in ET-plants when compared with NET-plants. The $S$ content in root first decreased by approximately $25 \%$ at $\mathrm{Cr} 20$ and $\mathrm{Cr} 40$, respectively, and then increased by $28.63 \%$ at $\mathrm{Cr} 60$, their corresponding controls. Whereas, the EDTA application increased $\mathrm{N}$ and $\mathrm{S}$ contents in shoot at all $\mathrm{Cr}(\mathrm{VI})$ concentrations and the 
maximum increase in $\mathrm{N}$ and $\mathrm{S}$ was observed by $50.74 \%$ and $284.35 \%$ at $\mathrm{Cr} 40$, respectively, in ET-plants when compared with NET-plants.
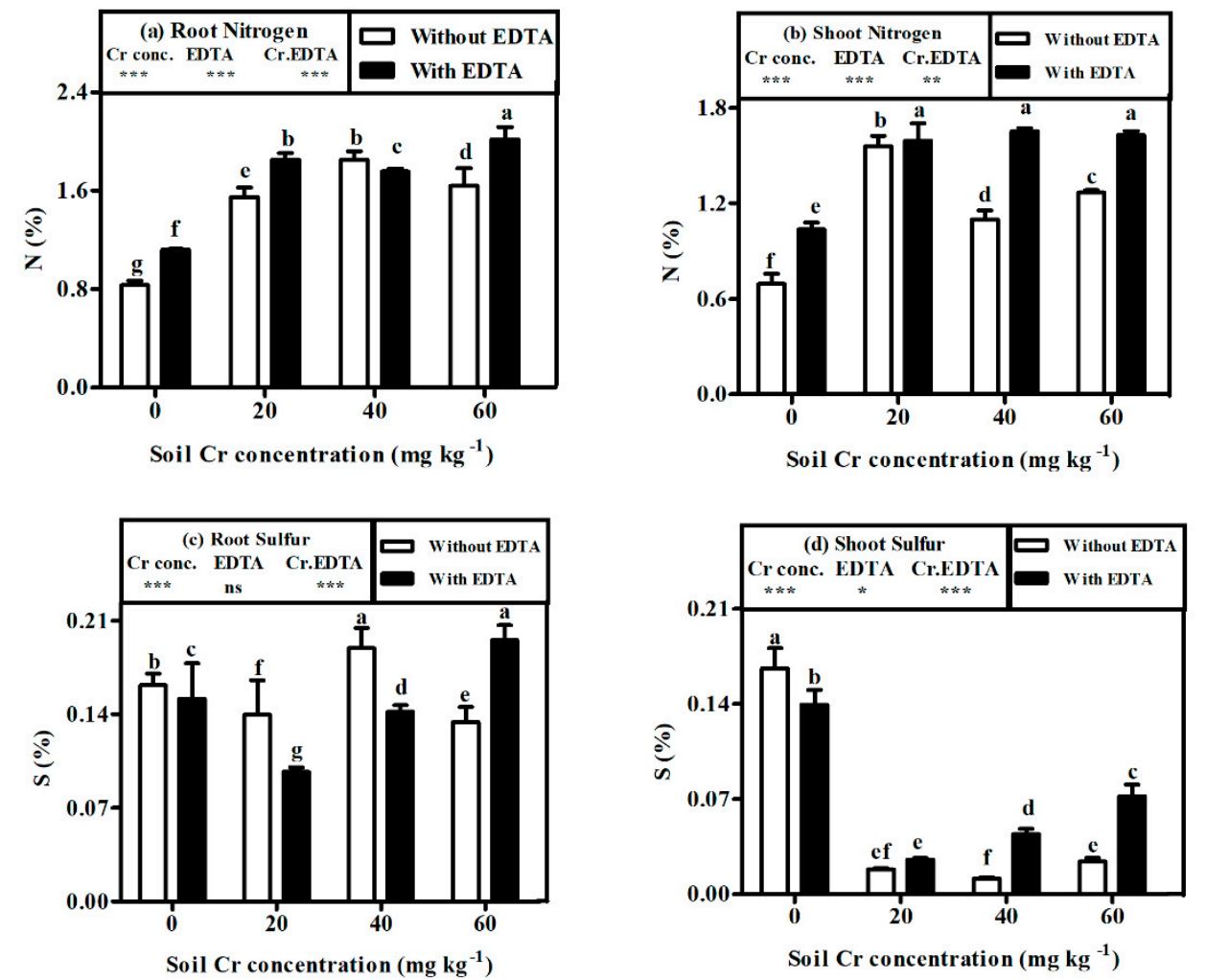

Figure 3. Influence of various $\mathrm{Cr}(\mathrm{VI})$ concentrations in soil on element levels (\%) of (a) root nitrogen, (b) shoot nitrogen, (c) root sulfur, and (d) shoot sulfur of hybrid Napier grass with and without EDTA application. Bars with dissimilar letters are significantly different at $p<0.05$ from Tukey's test. Values are means $\pm \mathrm{SE}, n=5 .{ }^{*} p<0.05 ;{ }^{* *} p<0.001 ;{ }^{* * *} p \leq 0.001$. ns: non-significant, $\mathrm{Cr}$ conc.: soil $\mathrm{Cr}(\mathrm{VI})$ concentration effect; EDTA: EDTA effect and Cr conc. EDTA: $\mathrm{Cr}(\mathrm{VI})$ conc. $\times$ EDTA interaction effect.

\subsection{Oxidative Stress}

Decreased tolerance was associated with increased oxidative stress in hybrid Napier grass that was grown in soil with varying concentrations of $\mathrm{Cr}(\mathrm{VI})$ stress. (Figure $4 \mathrm{a}-\mathrm{h})$. Overall, the malondialdehyde (MDA) level (Figure 4a,b) and activities of anti-oxidative enzymes, including superoxide dismutae (SOD), peroxidase (POD), and catalase (CAT) (Figure $4 c-h$ ), invariably increased with all tested $\mathrm{Cr}(\mathrm{VI})$ doses. The respective maximum increase in oxidative stress markers in the root and shoot of NET-plants were observed as MDA (19.21\% and 140.5\%), SOD (43.29\% and $123.37 \%)$, POD (59.36\% and $69.1 \%)$, and CAT $(27.17 \%$ and $135.82 \%)$ at Cr60 as compared with control. Whereas, in ET-plants, maximum increase in root and shoot (MDA $106.64 \%$ and $180.69 \%)$, SOD $(41.52 \%$ and $198.2 \%)$, POD $(78.41 \%$ and $86.93 \%)$, and CAT (41.45\% and $232.99 \%$ ) were observed at Cr60 when compared with control.

EDTA application aggravated the effects of $\mathrm{Cr}(\mathrm{VI})$ on MDA level and antioxidant enzyme activities in the root and shoot of the plant. The MDA level, SOD, and CAT activities increased by $44.29 \%, 9.5 \%$, and $44.3 \%$, respectively, at Cr60, and the POD activity increased by $18.3 \%$ at Cr20 in root of ET-plants as compared with that of NET-plants. Whereas, in shoot, the MDA level, SOD, and CAT activities increased by $43.9 \%, 15.2 \%$, and $43.9 \%$, respectively, at Cr20, and the POD activity increased by $15.2 \%$ at $\mathrm{Cr} 40$ in ET-plants when compared with that of NET-plants. Concurrent with increased toxicity, the oxidative stress was higher in the shoot than in root of both NET-plants and ET-plants. 

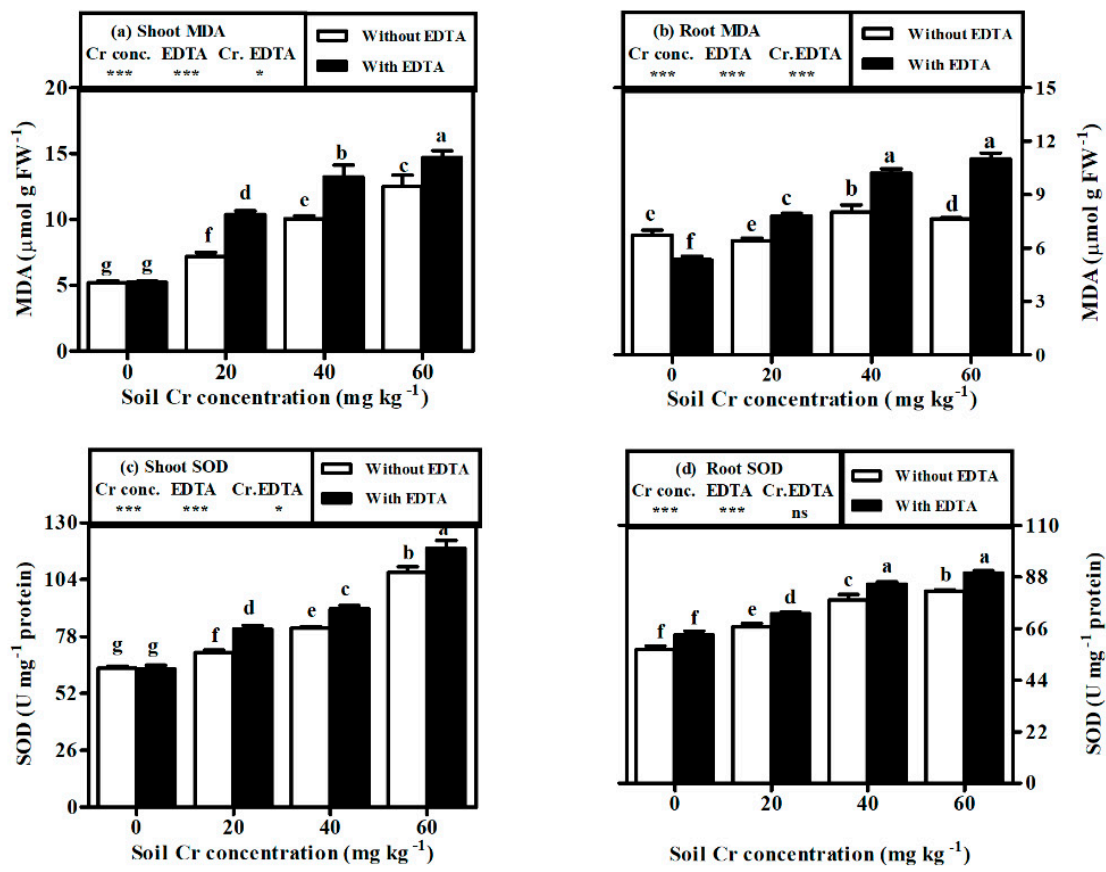

Soil Cr concentration $\left(\mathrm{mg} \mathrm{kg}^{-1}\right)$
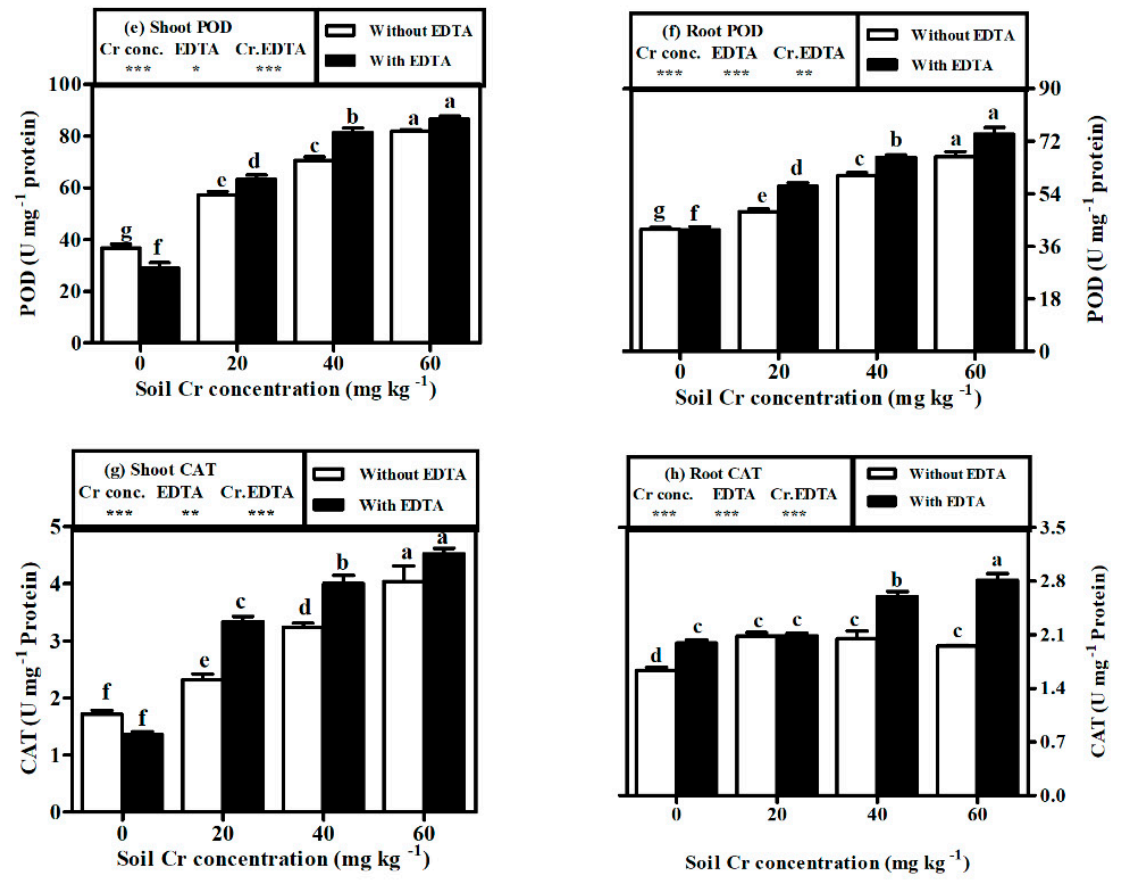

Figure 4. Influence of various $\mathrm{Cr}(\mathrm{VI})$ concentrations in soil on (a) malondialdehyde (MDA) level in shoot, (b) MDA level in root, (c) superoxide dismutase (SOD) activity in shoot, (d) SOD activity in root (e) peroxidase (POD) activity in shoot, (f) POD activity in root (g) catalase (CAT) activity in shoot and (h) CAT activity in root of hybrid Napier grass with and without EDTA application. Bars with dissimilar letters are significantly different at $p<0.05$ from Tukey's test. Values are means $\pm \mathrm{SE}, n=5$. ${ }^{*} p<0.05 ;{ }^{* *} p<0.001$; ${ }^{* * *} p \leq 0.001$. ns: non-significant, $\mathrm{Cr}$ conc.: soil $\mathrm{Cr}$ (VI) concentration effect; EDTA: EDTA effect and $\mathrm{Cr}$ conc. EDTA: $\mathrm{Cr}(\mathrm{VI})$ conc. $\times$ EDTA interaction effect. 


\section{Discussion}

\subsection{Plant Growth and Phytotoxicity}

In our study, $\mathrm{Cr}(\mathrm{VI})$ negatively affected the growth of hybrid Napier grass and reduced the plant yield and biomass in dose-dependent manner. The adverse effects of $\mathrm{Cr}(\mathrm{VI})$ on plant growth have been well documented [27-29]. A reduction in biomass and plant yield is caused by the stunted growth of shoot and leaf, which might be due to the toxic effects of $\mathrm{Cr}(\mathrm{VI})$ on photosynthesis and it might be partially due to a reduced transport of water and nutrients from soil caused by reduced root growth in presence of $\mathrm{Cr}(\mathrm{VI})[22,28]$. Reduced root growth might be due to tissue collapse resulting from the inhibition of proliferation and elongation of root consequently result in incapability of the roots to absorb water and nutrients from the medium $[9,30]$.

As a consequence of biomass reduction, the $\mathrm{Cr}(\mathrm{VI})$ stress reduced the tolerance indices (TI) of hybrid Napier grass in dose-dependent manner and the application of EDTA enhanced the Cr(VI) toxicity in plant. The most significant effects of EDTA were observed on DW of root and shoot. Our findings are in accordance with Bareen et al. [31], who reported increased phytotoxic effects in sorghum (Sorghum bicolor) and pearl millet (Pennisetum glaucum) species that were treated with $\mathrm{Cr}(\mathrm{VI})$ and EDTA co-application than $\mathrm{Cr}(\mathrm{VI})$-alone, and the most severe toxic effects were observed on root length. The inhibitory effects of EDTA on growth and the reduction of dry biomass have been reported in marigold (Tagetes sp.) [32]. The decrease in DW of root and shoot of the plant following EDTA application can be attributed to EDTA toxicity and Cr-EDTA chelant complex formation [31]. One of the reasons of negative effects of EDTA can be the impaired absorption of essential nutrients, such as $\mathrm{Zn}^{2+}$ and $\mathrm{Ca}^{2+}$, due to increased mobilization of heavy metal in the soil, which negatively impacts the cell wall elasticity and viscosity, reduce cell division and transpiration, and impair the cell membranes [31,32]. Moreover, the $\mathrm{Cr}(\mathrm{VI})$ toxicity was higher in the shoot than in root of hybrid Napier grass. Amin et al. [27] studied the effects of varying $\mathrm{Cr}(\mathrm{VI})$ contaminations (0.5-75 $\left.\mathrm{mg} \mathrm{Cr} \mathrm{kg}^{-1} \mathrm{soil}\right)$ in several plant species observed that toxic effects of $\mathrm{Cr}(\mathrm{VI})$ were greater in shoots than in roots of the plants.

\subsection{Cr Accumulation and Phytoremediation Potential}

In this study, $\mathrm{Cr}$ accumulation in the root and shoot increased with increasing $\mathrm{Cr}(\mathrm{VI})$ concentrations in soil and the maximum increase occurred at the highest concentration (Cr60). The amount of Cr(VI) uptake, transport, and accumulation in different organs of the plant vary with species and it depends upon the dosage and period of $\mathrm{Cr}(\mathrm{VI})$ treatment [22]. The seedlings of maize (Zea mays) cultivated in soil contaminated with 10 and $20 \mathrm{mg} \mathrm{kg}^{-1} \mathrm{Cr}(\mathrm{VI})$ for 30 days accumulated 15.2 and $16.3 \mathrm{mg} \mathrm{kg}^{-1} \mathrm{of} \mathrm{Cr}_{\text {, }}$ respectively [33]. Whereas, the exposure of gram (Cicer arietinum L.) seedlings to $\mathrm{Cr}(\mathrm{VI})$ stress at doses of 25,50 , and 75 ppm resulted in $\mathrm{Cr}$ accumulation of up to $0.2,0.5$, and $0.1 \mathrm{~g} \mathrm{~kg}^{-1}$ in roots, and $0.085,0.2$ and $0.05 \mathrm{~g} \mathrm{~kg}^{-1}$ in shoot, respectively [30]. Similarly, $\mathrm{Cr}$ accumulation ranged between $10-30 \mathrm{mg} \mathrm{kg}^{-1}$ DW in paddy (Oryza sativa L) seedlings that were treated with 2.5-200 $\mathrm{mg} \mathrm{L}^{-1} \mathrm{Cr}(\mathrm{VI})$ [34].

$\mathrm{Cr}$ accumulation was higher in roots than in the shoot of hybrid Napier grass. Huffman and Allaway [35] found that bean and wheat (Triticum aestioum) plants accumulated over 90\% $\mathrm{Cr}$ in their roots, while seeds accumulated about $0.1 \%$. Greater retention in roots can be attributed to reduced $\mathrm{Cr}$ transport from root to aerial parts of plant. Cr immobilization either by compartmentalization in vacuoles or retention in cation exchange sites of xylem parenchyma cells causes $\mathrm{Cr}$ accumulation in root, which is indeed a defensive strategy adapted by plant against metal toxicity [36]. Certain small sized proteins behave as natural chelates, bind as cation with the $\mathrm{Cr}$ ions, and inhibit its transport [30]. A reduction of $\mathrm{Cr}(\mathrm{VI})$ to low soluble form $\mathrm{Cr}(\mathrm{III})$ might be another possible reason of higher $\mathrm{Cr}$ accumulation in roots [22].

The bioaccumulation factor is the ratio of concentration of metal in shoot to that in soil. Bioaccumulation process is the ability of plant to convert and store the toxic metals into non-toxic or less toxic forms in various plant organs [37]. The values for BAF of hybrid Napier grass were greater 
than 1 , which indicate the $\mathrm{Cr}(\mathrm{VI})$ tolerance capability of shoot of the plant. However, the TF values were lower than 1 , which suggests the restricted ability of hybrid Napier grass to transport the $\mathrm{Cr}$ from root to shoot $[27,38]$. The hybrid Napier might be classified as $\mathrm{Cr}(\mathrm{VI})$ excluder because of its ability to effectively restrict the $\mathrm{Cr}$ transport and maintain relatively low $\mathrm{Cr}$ levels in shoot over a wide range of soil $\mathrm{Cr}(\mathrm{VI})$ contamination [39]. Moreover, the plant species would be applicable for $\mathrm{Cr}(\mathrm{VI})$ phytostabilization due to its BAF values $>1$ and a relatively low TF value $[7,40]$. Furthermore, hybrid Napier grass is edible to animals; its ability to stabilize toxic metal in the root and limited transport to aerial (edible) parts of plant would prevent animal's ingestion, restrict soil mobility, and consequently reduce transmission across the food chain.

EDTA application enhanced $\mathrm{Cr}$ uptake and accumulation in ET-plants when compared with NET-plants. In addition, $\mathrm{Cr}$ accumulation was comparatively higher in the shoot of ET-plant, which is due to the increased transfer factor in ET-plants as compared with NET-plants. Increased Cr uptake from soil and its transport from roots to aerial parts of the plants have been reported in Indian mustard (Brassica juncea) [4] and rapeseed (Brassica. Napus L.) [5]; and, in oats (Avena sativa), sesame (Sesamum indicum), Soyabean (Glycine max), okra (Abelmoschus esculentus), spinach (Spinacia oleracea), wheat, and sorghum [27]. EDTA either binds with $\mathrm{Cr}$ to form Cr-EDTA complex or increases the concentrations of soluble and exchangeable form of $\mathrm{Cr}$ by lowering soil $\mathrm{pH}$ and, thus, increases the bioavailability and facilitates the transport [24]. In the present study, the BAF and TF both increased with increasing $\mathrm{Cr}(\mathrm{VI})$ concentrations in soil and the EDTA application resulted in further enhancement of their values. Han et al. [4] and Ebrahimi et al. [7] reported an increase in both $\mathrm{Cr}$ accumulation factor and transfer factor with increasing $\mathrm{Cr}(\mathrm{VI})$ contamination in the soil and the EDTA addition led to a further increase in their values in common reed (Phragmites australis (Cav.) Trin. Ex Steudel) and Indian mustard.

\subsection{Chlorophyll and Photosynthetic Efficiency}

Consistent with our results, several studies have reported a decrease in chlorophyll with increasing $\mathrm{Cr}(\mathrm{VI})$ concentrations in soil. Two varieties of Catharanthus roseus (L.) i.e., C. rosea and C. alba grown in $\mathrm{Cr}(\mathrm{VI})$ contaminated soil for 30 days showed a reduction in chlorophyll by $10.56 \%$ and $4.72 \%$, respectively [22]. The chlorosis effect of $\mathrm{Cr}(\mathrm{VI})$ might be due to its inhibitory effects on one or more enzymes that are involved in chlorophyll biosynthesis or it may be due to the damage of associated proteins $[40,41]$.

$\mathrm{Cr}(\mathrm{VI})$ has been shown to impair photosynthesis either directly or indirectly by affecting one or more structural or functional components of photosynthetic machinery $[23,30]$. The efficiency of plant pigments to capture and convert light energy is represented by the Fv/Fm ratio, which is an excellent measurement of overall maximum quantum yield efficiency of photosystem-II (PSII) [28]. A reduction in the $\mathrm{Fv} / \mathrm{Fm}$ ratio in our study suggests that $\mathrm{Cr}(\mathrm{VI})$ decreased the quantum efficiency of PSII photochemistry in hybrid Napier grass. Previous studies have reported a dose-dependent linear decrease in the $\mathrm{Fv} / \mathrm{Fm}$ ratio with $\mathrm{Cr}(\mathrm{VI})$ concentrations between 0 to $300 \mu \mathrm{M}$ in rice and wheat seedlings [23,28]. FV/Fm also specifically represents the overall efficiency of open PSII centers and photochemical quenching (qP) represents the number of open PSII centers [28,42]. In the present study, a concurrent decrease in $\mathrm{qP}$ and $\mathrm{Fv} / \mathrm{Fm}$ suggests that $\mathrm{Cr}(\mathrm{VI})$ stress caused the shut down of some PSII centers as well as slowed down the efficiency of open PSII centers. Mathur et al. [28] reported that $\mathrm{Cr}(\mathrm{VI})$ stress reduced the active PSII centers count and thereby reduced its density in rice seedlings. In addition, lowered $\mathrm{qP}$ is associated with a simultaneous increase in $\mathrm{qN}$ [42]. In our study, maximum increase in $\mathrm{qN}$ by $49 \%$ reflects the dissipation of a huge amount of excitation energy under $\mathrm{Cr}(\mathrm{VI})$ stress [23]. Moreover, elevated qN inhibits NADPH and ATP utilization following the $\mathrm{Cr}(\mathrm{VI})$-induced reduction of $\mathrm{CO}_{2}$ assimilation and ultimately leads to the impairment of photosynthetic electron transport (ETR) [42]. Consistently, decreased ETR by $17.6 \%$ in the present study reflects impaired electron flow. Obstructed electron flow from the reaction center to Quinone pool has been reported in rice seedlings under $\mathrm{Cr}(\mathrm{VI})$ stress [28]. One of the reasons of impaired electron flow in the present study may be the $\mathrm{Cr}(\mathrm{VI})$-induced reduction in activity of water-splitting complex, as observed by a 
$29 \%$ decline in Fv/Fo. Similarly, Mathur et al. [28] observed a 30\% decrease in Fv/Fo in wheat plantlets that were treated with $300 \mu \mathrm{M}$ Cr(VI). Reduced Fv/Fo also represents structural damage, such as loss of thylakoid membranes, etc., in the chloroplast and it is a more reliable criterion in evaluating the photochemical activity $[28,41]$.

With EDTA application, the damaging effects of $\mathrm{Cr}(\mathrm{VI})$ on photosynthetic activity were more pronounced, as shown by severe decrease in $\mathrm{Fv} / \mathrm{Fm}, \mathrm{Fv} / \mathrm{Fo}$, and ETR, by $31.63 \%, 134 \%$, and $57.5 \%$, respectively, and a increase in qN by $314 \%$ at $\mathrm{Cr} 60$ with EDTA addition (ET-plants) as compared with that of without EDTA addition (NET-plants). The toxic effects of $\mathrm{Cr}(\mathrm{VI})$ on photochemical parameters increase with the increase in amount of $\mathrm{Cr}$ in plant tissues [22]. The severe damage of photosynthetic activity in ET-plants might be attributed to greater $\mathrm{Cr}$ concentrations in leaves (shoot) of the plant, which was two times higher in the shoots of ET-plants as compared with NET-plants that might result from a EDTA-induced increase in the metal transport.

\subsection{Elemental Status}

Though, there was variable response of different $\mathrm{Cr}(\mathrm{VI})$ concentrations in soil on contents of $\mathrm{N}$ and $\mathrm{S}$ in hybrid Napier grass, but, in general, the $\mathrm{Cr}(\mathrm{VI})$ stress showed an increasing trend in $\mathrm{N}$ contents and decreasing trend in S content in root and shoot of the plant. Consistently, Wyszkowski and Radziemska [43] observed that soil contamination with $\mathrm{Cr}(\mathrm{VI})$ raised the $\mathrm{N}$ content by $21 \%$ and $37.5 \%$ in oats roots and straw, respectively, and the $\mathrm{N}$ accumulation was higher in the upper regions of maize and spring barley (Hordeum vulgare L.) [44]. The $\mathrm{Cr}(\mathrm{VI})$ stress produced variable effects on S contents in plants. S contents decreased in leaves, but increased in the stem and root of citrullus (Citrullus vulgaris cv. Ludhiana) cultivated in $\mathrm{Cr}(\mathrm{VI})$ contaminated soil [45]. Whereas, $\mathrm{S}$ content decreased in roots of Brassica juncea (L.) seedlings that were grown under Cr(VI) stress [46].

EDTA application further escalated the effects of $\mathrm{Cr}(\mathrm{VI})$ on contents of $\mathrm{N}$ and $\mathrm{S}$ in the plant. Generally, the contents of $\mathrm{N}$ increased and that of $\mathrm{S}$ decreased in root and shoot of the plant. Consistent with our findings, Zheng et al. [47] reported an increase in N content of Lespedeza chinesis and L. davidii with an increase in soil $\mathrm{Pb}$ concentrations and the addition of EDTA caused a further increase in the $\mathrm{N}$-content of the plant. The mechanism that is involved in the reduction of $\mathrm{S}$ content in plant might be explained by the reason that $\mathrm{Cr}(\mathrm{VI})$ either competitively inhibits binding site and/or decrease sulfate transporter (BjST1) mRNA expression [46]. The Cr(VI)-induced S deficiency impairs S incorporation in some essential amino acids, thereby decreasing S-containing protein contents and eventually leading to stunted plant growth [48].

\subsection{Oxidative Stress}

In our study, the reduced tolerance was associated with simultaneous increase in oxidative stress in the plant. It has been suggested that $\mathrm{Cr}(\mathrm{VI})$-induced impairment in biochemical pathways, such as photosynthesis and chlorophyll biosynthesis, are at least partly caused by oxidative stress. $\mathrm{The} \mathrm{Cr}(\mathrm{VI})$ contamination causes an imbalance between reactive oxygen species (ROS), such as $\mathrm{H}_{2} \mathrm{O}_{2}$, and alters the activities of antioxidant enzymes and, thus, causes oxidative stress in leaves, shoot, and roots of the plants [49]. MDA is a product of lipid peroxidation that is used as an important marker of oxidative stress [36]. The increased MDA contents by $19.21 \%$ and $140.5 \%$ in root and shoot in our study signifies that $\mathrm{Cr}(\mathrm{VI})$ induced oxidative stress in the studied plant. Consistently, Upadhyay and Panda [50] observed an increase in MDA content by $182 \%$ and $140 \%$ in the root and shoot of water lettuce (Pistia stratiotes L.) at $10 \mathrm{mM} \mathrm{Cr}(\mathrm{VI})$ as compared with control. Similarly, Cr stress elevated the MDA contents in roots of cotton cultivars [51] and leaves of maize [49]. Concomitant with MDA content, we found an increase in activities of SOD by $43.29 \%$ and $123.37 \%$, POD by $59.36 \%$ and $69.1 \%$, and CAT by $27.17 \%$ and $135.82 \%$ in root and shoot of $\mathrm{Cr}(\mathrm{VI})$ stressed plants, respectively, when compared with control. Moreover, a dose-dependent increase in the activities of these antioxidants has been reported in roots of cotton cultivars [41] and leaves of maize [49]. 
The magnitude of oxidative stress induction was greater in the root and shoots of the plant with increasing $\mathrm{Cr}(\mathrm{VI})$ concentrations and further increased with the application of EDTA as compared with that of without EDTA application. The increase in enzyme activities suggested the induction of stress by $\mathrm{Cr}(\mathrm{VI})$, as there were no significant changes in enzyme activities among the controls (with and without EDTA). Similarly, Khan et al. [52] reported that the exposure of Petunia hybrida L. to Cr resulted in significantly higher antioxidant enzyme activity, which was enhanced with the increasing concentrations of $\mathrm{Cr}$, and co-addition of EDTA along with $\mathrm{Cr}$. The increasing toxic effects of $\mathrm{Cr}(\mathrm{VI})$ in combination with EDTA treatment might be related to increased toxicity with higher uptake and accumulation of Cr by EDTA treatment. Han et al. [4] reported that EDTA treatment increased the accumulation of $\mathrm{Cr}$ in $\mathrm{B}$. juncea, which consequently resulted in growth retardation, reduction of the number of palisade, and spongy parenchyma cells in leaves, clotted depositions in the xylem, and phloem tissues of stems and roots.

\section{Materials and Methods}

\subsection{Seed Collection and $\mathrm{Cr}(V I)$ Stock Solution Preparation}

Seeds of hybrid Napier grass were purchased from Lizhiyuan seed company, Mianyang, China. Before sowing, the seeds were treated with $0.1 \%$ mercuric chloride $\left(\mathrm{HgCl}_{2}\right)$ solution for $10 \mathrm{~min}$. and then washed with distilled water to avoid any infection [27]. Stock solution of $\mathrm{Cr}(\mathrm{VI})\left(1000 \mathrm{mg} \mathrm{L}^{-1}\right)$ was prepared by dissolving potassium dichromate $\left(\mathrm{K}_{2} \mathrm{Cr}_{2} \mathrm{O}_{7}, 2.83 \mathrm{~g}\right)$ in deionized water $(1000 \mathrm{~mL})$. The stock solution was then appropriately diluted to get test solution of desired $\mathrm{Cr}(\mathrm{VI})$ concentrations.

\subsection{Soil Collection and Seedling Growth}

Soil was sampled from farmland far from $\mathrm{Cr}$ contamination source in Mianyang, China. The coordinates of the sampling points were determined while using a Macellel Model GPS and the locations of the sampling points are (coordinates, $31.550074 \mathrm{E}-104.640345 \mathrm{~N}$ ). Five soil samples were collected from surface layer up to $30 \mathrm{~cm}$ depth and within a distance of $5 \mathrm{~m}$ surrounding the site to form a composite sample. After air drying, the samples were crushed to pass through a size of $2 \mathrm{~mm}$ sieve. Prior the experiment, a soil sample was analyzed for some physico-chemical properties, as presented in Table 4. The sieved soil was placed on waterproof tarpaulin and mixing $\mathrm{Cr}(\mathrm{VI})$ solution to obtain appropriate $\mathrm{Cr}(\mathrm{VI})\left(20,40\right.$, and $\left.60 \mathrm{mg} \mathrm{kg}^{-1}\right)$ concentrations in soil. The soil was then allowed a minimum period of 30 days for stabilization. Soil without any amendment was used as control. Meanwhile, the seeds were sown about $1 \mathrm{~cm}$ deep in uncontaminated soil filled in small polyethylene bags for seedlings (one seed per one bag).

Table 4. Physico-chemical properties of the background soil.

\begin{tabular}{lc}
\hline \multicolumn{1}{c}{ Properties } & Determined Value \\
\hline Sand (\%) & $1.4 \pm 0.052$ \\
Silt $(\%)$ & $23.9 \pm 0.56$ \\
Clay $(\%)$ & $74.7 \pm 0.84$ \\
$\mathrm{pH}$ & $6.0 \pm 0.06$ \\
Texture class & Silty clay \\
Electrical conductivity $\left(\mathrm{mS} \mathrm{m}^{-1)}\right.$ & $0.71 \pm 0.28$ \\
Total Carbon $(\mathrm{C}, \%)$ & $0.132 \pm 0.002$ \\
Hydrogen $(\mathrm{H}, \%)$ & $0.381 \pm 0.007$ \\
Nitrogen $(\mathrm{N}, \%)$ & $0.057 \pm 0.002$ \\
Sulfur $(\mathrm{S}, \%)$ & $0.003 \pm 0$ \\
Total chromium $\left(\mathrm{Cr}_{\text {total }}, \mathrm{mg} \mathrm{kg}^{-1}\right)$ & $0.0104 \pm 0$ \\
\hline
\end{tabular}




\subsection{Experimental Design}

Pot experiment was carried out in a completely randomized design (CRD) in naturally lit greenhouse at Southwest University of Science and Technology (SWUST), Mainyang, China, under ambient conditions. Pots ( $1 \mathrm{~L}$ in volume with dimensions; $11 \mathrm{~cm}$ height $\times 13 \mathrm{~cm}$ top diameter $\times 10 \mathrm{~cm}$ bottom diameter) were individually filled with $1 \mathrm{~kg}$ of uncontaminated and $\mathrm{Cr}(\mathrm{VI})$-contaminated soil with varying $\mathrm{Cr}(\mathrm{VI})$ concentrations, respectively. The pots were equilibrated for $24 \mathrm{~h}$ and the seedlings of hybrid Napier grass (20 days older and uniform) were then transferred into pots. Experimental setup comprised of two; viz. non-EDTA-treated (NET) and EDTA-treated (ET) groups with four treatments (10 plants/treatment) in each group (Table 5). The treatments in NET group included Cr0 or control (plants grown in uncontaminated soil) and $\mathrm{Cr} 20, \mathrm{Cr} 40$, and $\mathrm{Cr} 60$ (plants grown in soil contaminated with $\mathrm{Cr}(\mathrm{VI})$ levels of 20,40, and $60 \mathrm{mg} \mathrm{kg}^{-1}$, respectively) without any EDTA amendment. Whereas, in the ET group, the four treatments $\mathrm{Cr} 0, \mathrm{Cr} 20, \mathrm{Cr} 40$, and $\mathrm{Cr} 60$ followed similar pattern as in NET, amended with EDTA at the dose rate of $4 \mathrm{mM}$, applied once to the soil at 15 days after transfer of the seedlings. The plants were watered to $100 \%$ of field capacity (soil water content maintained at $41.9 \%$ ). Each pot was placed in plastic saucers to collect leachates that were added back into pot soil regularly to minimize the loss of $\mathrm{Cr}(\mathrm{VI})$ and EDTA in the system. After seedlings transfer, the pot experiment lasted for 45 days; thereafter, the plants were harvested, sampled, and analyzed accordingly.

Table 5. Experimental design showing groups and treatments.

\begin{tabular}{cccccccccc}
\hline \multirow{2}{*}{ Treatments } & \multicolumn{9}{c}{ Groups } \\
\cline { 2 - 10 } & Cr0 & Cr20 & Cr40 & Cr60 & Cr0 & Cr20 & Cr40 & Cr60 \\
\cline { 2 - 9 } & 0 & 20 & 40 & 60 & 0 & 20 & 40 & 60 \\
Soil Cr(VI) conc. $\left(\mathrm{mg} \mathrm{k}^{-1}\right)$ & - & - & - & - & 4 & 4 & 4 & 4 \\
EDTA (mM) & - &
\end{tabular}

EDTA: Ethylene diamine tetra acetic acid; NET-plants: Non-EDTA-treated plants; ET-plants: EDTA-treated plants.

\subsection{Growth Measurements}

Five plants from each treatment were thoroughly rinsed and then cut into roots and shoots. After measurement of shoot height $(\mathrm{cm})$, root length $(\mathrm{cm})$, and leaf area $\left(\mathrm{cm}^{2}\right)$ by using scale, the samples were then oven dried at $80{ }^{\circ} \mathrm{C}$ for $48 \mathrm{~h}$ and dry weights $\left(\mathrm{g} \mathrm{plant}^{-1}\right.$ ) were measured while using analytical weight balance.

\subsection{Cr Analysis}

The Cr concentrations in plant (shoot and root) and soil samples were determined through the acid digestion method, as described by Diwan et al. [36]. Briefly, the shoot $(200 \mathrm{mg})$ and root $(100 \mathrm{mg})$ samples were digested with a $5 \mathrm{~mL}$ mixture of $\mathrm{HNO}_{3}$ and $\mathrm{H}_{2} \mathrm{O}_{2}(4: 1 \mathrm{v} / \mathrm{v})$, whereas the soil $(1000 \mathrm{mg})$ samples were digested with $\mathrm{HNO}_{3} / \mathrm{HCl}$ solution (3:1 v/v). The sample digestion was taken in a Teflon digestion vessel while using microwave-assisted digestion system (MDS-6G) for $15 \mathrm{~min}$. to $120^{\circ} \mathrm{C}$, $15 \mathrm{~min}$. to $190{ }^{\circ} \mathrm{C}$, and $30 \mathrm{~min}$. at $190^{\circ} \mathrm{C}$. The digested samples were finally diluted with deionized water to make a final volume up to $50 \mathrm{~mL}$ for subsequent $\mathrm{Cr}$ analysis through Inductively coupled plasma-optical emission spectrometry (ICP-OES; Varian 715-ES ICP-OES; Varian, Palo Alto, CA, USA). The $\mathrm{Cr}$ concentration and accumulation in root and shoot of the plant were calculated, as described by Farid et al. [53].

Cr accumulation $\left(\mathrm{mg} \mathrm{plant}^{-1}\right)=\mathrm{Cr}$ concentration in organ $\left(\mathrm{mg} \mathrm{kg}^{-1}\right) \times$ Dry weight of organ $(\mathrm{kg})$

\subsection{Phytoremediation Potential}

The bioaccumulation factor (BAF) and transfer factor (TF) of the metal were measured to determine the phytoremediation potential of the plant. BAF is the ratio of metal concentration in shoot to that in 
soil and TF is the ratio of metal concentration in plant shoot to that in roots [27]. BAF and TF were calculated as:

$$
\begin{aligned}
\mathrm{BAF} & =\mathrm{C}_{\text {shoot }}\left(\mathrm{mg} \mathrm{kg}^{-1} \mathrm{DW}\right) / \mathrm{C}_{\text {soil }}\left(\mathrm{mg} \mathrm{kg}^{-1} \mathrm{DW}\right) \\
\mathrm{TF} & =\mathrm{C}_{\text {shoot }}\left(\mathrm{mg} \mathrm{g}^{-1} \mathrm{DW}\right) / \mathrm{C}_{\text {root }}\left(\mathrm{mg} \mathrm{g}^{-1} \mathrm{DW}\right)
\end{aligned}
$$

where, $\mathrm{C}_{\text {shoot}}, \mathrm{C}_{\text {root}}$, and $\mathrm{C}_{\text {soil }}$ are $\mathrm{Cr}$ concentrations in shoot, root, and soil, respectively.

\subsection{Tolerance Index (TI)}

The tolerance index (TI) was determined as the ratio between biomass (DW) of a $\mathrm{Cr}(\mathrm{VI})$ treated plant to that of a control plant [27], as follows:

$$
\mathrm{TI}=\text { Biomass of the treated plants }\left(\mathrm{g} \mathrm{plant}^{-1}\right) / \text { Biomass of the control plants }\left(\mathrm{g} \mathrm{plant}^{-1}\right)
$$

\subsection{Determination of Chlorophyll Content, Chlorophyll- $\alpha$ Fluorescence and Elemental Contents}

The chlorophyll (Chl) content was non-invasively determined in the flag leaf while using a portable chlorophyll meter SPAD 502 (Minolta, Japan) [54]. The value of chlorophyll (Chl) content $\left(\mathrm{mg} \mathrm{m}^{-2}\right)$ was estimated from corresponding SPAD values by using the following equation:

$$
\text { Chl content } \left.\left(\mathrm{mg} \mathrm{m}^{-2}\right)=15.68 \text { (SPAD units }\right)-209.03
$$

Chlorophyll- $\alpha$ fluorescence was measured in five intact and healthy flag leaves through fluorometer (FMS2 from Hansatech Instruments Ltd., Norfolk, UK). After an adjustment period of $30 \mathrm{~min}$. in the dark, the leaves were exposed to beam light as per the method adapted by Paiva et al. [41]. The maximum photosynthetic efficiency of PSII ( $\Phi$ PSII = Fv/Fm), efficiency of water-splitting complex $(\mathrm{Fv} / \mathrm{Fo})$, and variable fluorescence $(\mathrm{Fv}=\mathrm{Fm}-\mathrm{Fo})$ were calculated, where Fo and Fm denote the minimum and maximum fluorescence, respectively.

The contents (\%) of nitrogen (N) and sulfur (S) in the root and shoot were analyzed through elemental analyzer (Vario EL cube; Elementar Analysensysteme, Langenselbold, Germany). The dried samples were ground into fine powder. The powdered samples $(10 \mathrm{mg})$ were subjected to elemental analysis and the results were expressed in percentage (\%).

\subsection{Measurement of Oxidative Stress Parameters}

The homogenized tissue (shoots and roots) samples were analyzed for oxidative stress parameters, as described by Anjum et al. [39]. Malondialdehyde (MDA, kit A003-1) level and activities of superoxide dismutase (SOD, EC 1.15.1.1, kit A001-1), peroxidase (POD, kit A084-3), and catalase (CAT, EC 1.11.1.6, kit A007-1) in plant tissues were quantified by using assay kits (Nanjing Jiancheng Bioengineering Institute, Nanjing, China). Briefly, the MDA content ( $\left.\mu \mathrm{mol} \mathrm{g}^{-1} \mathrm{FW}\right)$ was measured at $535 \mathrm{~nm}$ as an amount of MDA and thiobarbituric acid (TBA) mixture produced as a result of a reaction of MDA in samples with TBA. SOD activity was measured based on the inhibition of photochemical reduction of nitroblue tetrazolium (NBT) by $\mathrm{O}_{2} \bullet^{-}$radicals. The activities of CAT or POD were calculated as the rate of $\mathrm{H}_{2} \mathrm{O}_{2}$ decomposition.

\subsection{Statistical Analysis}

The data were checked for normality and the homogeneity of variances and log-transformed to correct the deviations from these assumptions when needed. All of the measurements were tested by a two-way ANOVA by using the SPSS 16.0 for Windows statistical software package (SPSS Inc., Chicago, IL, USA). Post-hoc comparisons were tested while using Tukey's test at a significance level of $p<0.05$. 


\section{Conclusions}

The results of the present study demonstrated that the contamination of soil with varying $\mathrm{Cr}(\mathrm{VI})$ concentrations increased $\mathrm{Cr}$ uptake and accumulation and negatively affected the growth of hybrid Napier grass in a dose-dependent manner. The $\mathrm{Cr}(\mathrm{VI})$ stress altered the levels of $\mathrm{N}$ and $\mathrm{S}$, reduced chlorophyll content, and impaired photosynthetic machinery associated with reduced tolerance and increased oxidative stress. In addition, EDTA application enhanced $\mathrm{Cr}$ uptake and accumulation, along with more $\mathrm{Cr}$ accumulation in the shoot of ET-plants than that of NET-plants due to enhanced transport. Moreover, the phytotoxic effects of $\mathrm{Cr}(\mathrm{VI})$ increased in the presence of EDTA than without EDTA treatment. Though the $\mathrm{Cr}(\mathrm{VI})$ and EDTA stress reduced tolerance, but even at the highest $\mathrm{Cr}(\mathrm{VI})$ concentration, the plant could exhibited strong resistance, as evidenced by an increase in SOD, POD, and CAT activities. The hybrid Napier might be classified as $\mathrm{Cr}$ excluder because of its ability to maintain relatively low $\mathrm{Cr}$ levels in shoot by effective restriction of the $\mathrm{Cr}$ transport $(\mathrm{TF}<1)$. Moreover, due to its BAF values $>1$ and TF $<1$, this plant species would be applicable for Cr phytostabilization. Furthermore, hybrid Napier grass is edible to animals; its ability to limit the toxic metal to aerial (edible) parts of plant would prevent animal's ingestion, restrict soil mobility, and consequent transmission across the food chain. However, this species needs to be further explored to understand the molecular mechanism of tolerance and remediation potential of $\mathrm{Cr}$, as well as other heavy metals with various chelant amendments, so that the plant can be best utilized in the field of phytoremediation.

Author Contributions: Conceptualization, F.D. and B.K.R.; methodology, F.D. and B.K.R.; software, B.K.R. and G.Y.; validation, F.D.; Q.L. and Y.H.; formal analysis, B.K.R. and Y.H.; investigation, B.K.R. and Y.H.; resources, F.D.; data curation, B.K.R. and Y.H.; writing—original draft preparation, B.K.R.; writing-review and editing, F.D.; B.K.R. and Y.H.; visualization, G.Y. and Q.L.; supervision, F.D.; project administration, F.D.; funding acquisition, F.D.

Funding: The research was supported by the Key Project of Natural Science Foundation of China (41831285).

Conflicts of Interest: The authors declare no conflict of interest.

\section{References}

1. Cheng, H.; Zhou, T.; Li, Q.; Lu, L.; Lin, C. Anthropogenic chromium emissions in China from 1990 to 2009. PLoS ONE 2014, 9, 87753. [CrossRef]

2. Shahid, M.; Shamshad, S.; Rafiq, M.; Khalid, S.; Bibi, I.; Niazi, N.K.; Rashid, M.I. Chromium speciation, bioavailability, uptake, toxicity and detoxification in soil-plant system: A review. Chemosphere 2017, 178, 513-533. [CrossRef] [PubMed]

3. da Conceição Gomes, M.A.; Hauser-Davis, R.A.; Suzuki, M.S.; Vitória, A.P. Plant chromium uptake and transport, physiological effects and recent advances in molecular investigations. Ecotoxicol. Environ. Saf. 2017, 140, 55-64. [CrossRef] [PubMed]

4. Han, F.X.; Sridhar, B.B.M.; Monts, D.L.; Su, Y. Phytoavailability and toxicity of trivalent and hexavalent chromium to Brassica Juncea. New Phytol. 2004, 162, 489-499. [CrossRef]

5. Adiloglu, S.; Süme, M.T.S.A. Chrome (Cr) pollution in agricultural areas improvement by phytoremediation method with Canola (Brassica napus L.) plant growing. J. Essent. Oil Bear. Plants JEOP 2015, 18, 1180-1186. [CrossRef]

6. Kalyvas, G.; Tsitselis, G.; Gasparatos, D.; Massas, I. Efficacy of EDTA and olive mill wastewater to enhance As, $\mathrm{Pb}$, and $\mathrm{Zn}$ phytoextraction by Pteris vittata $\mathrm{L}$. from a soil heavily polluted by mining activities. Sustainability 2018, 10, 1962. [CrossRef]

7. Ebrahimi, M. Effect of EDTA treatment method on leaching of $\mathrm{Pb}$ and $\mathrm{Cr}$ by Phragmites australis (Cav.) Trin. Ex Steudel (common reed). Caspian J. Environ. Sci. 2015, 13, 153-166.

8. Ma, Y.; Hooda, P.S. Trace Elements in Soils, 1st ed.; John Wiley \& Sons: Chichester, West Sussex, UK, 2010; pp. 461-480.

9. Shanker, A.K.; Cervantes, C.; Loza-Tavera, H.; Avudainayagam, S. Chromium toxicity in plants. Environ. Int. 2005, 31, 739-753. [CrossRef]

10. Isıklı, B.; Demir, T.; Ürer, S.; Berber, A.; Akar, T.; Kalyoncu, C. Effects of chromium exposure from a cement factory. Environ. Res. 2003, 91, 113-118. [CrossRef] 
11. Adriano, D.C. Trace Elements in the Terrestrial Environment; Springer: New York, NY, USA, 1986.

12. Mandal, A.; Voutchkov, M. Heavy metals in soils around the cement factory in Rockfort, Kingston, Jamaica. Int. J. Geosci. 2011, 2, 48. [CrossRef]

13. Kabata-Pendias, A. Trace Elements in Soils and Plants; CRC Press: Boca Raton, FL, USA, 2010.

14. Eriksson, J. Concentrations of 61 Trace Elements in Sewage Sludge, Farmyard Manure, Mineral Fertiliser, Precipitation and in Oil and Crops; Swedish Environmental Protection Agency: Stockholm, Sweden, 2001.

15. Takeda, A.; Kimura, K.; Yamasaki, S. Analysis of 57 elements in Japanese soils, with special reference to soil group and agricultural use. Geoderma 2004, 119, 291-307. [CrossRef]

16. Burt, R.; Wilson, M.; Mays, M.; Lee, C. Major and trace elements of selected pedons in the USA. J. Environ. Qual. 2003, 32, 2109-2121. [CrossRef] [PubMed]

17. Salminen, R.; Batista, M.; Bidovec, M. Part 1. Background Information, Methodology, and Maps. In FOREGS Geochemical Atlas of Europe; Geological Survey of Finland: Espoo, Finland, 2005.

18. Suseela, M.R.; Sinha, S.; Singh, S.; Saxena, R. Accumulation of chromium and scanning electron microscopic studies in Scirpus lacustris L. treated with metal and tannery effluent. Bull. Environ. Contam. Toxicol. 2002, 68, 540-548. [CrossRef]

19. Dixit, V.; Pandey, V.; Shyam, R. Chromium ions inactivate electron transport and enhance superoxide generation in vivo in pea (Pisum sativum L. cv: Azad) root mitochondria. Plant Cell Environ. 2002, 25, 687-693. [CrossRef]

20. Shanker, A.; Djanaguiraman, M.; Sudhagar, R.; Chandrashekar, C.; Pathmanabhan, G. Differential antioxidative response of ascorbate glutathione pathway enzymes and metabolites to chromium speciation stress in green gram (L.) R. Wilczek. cv CO 4 ) roots. Plant Sci. 2004, 166, 1035-1043. [CrossRef]

21. Choudhury, S.; Panda, S.K. Toxic effects, oxidative stress and ultrastructural changes in moss Taxithelium nepalense (Schwaegr.) Broth. under chromium and lead phytotoxicity. Water Air Soil Pollut. 2005, 167, 73-90. [CrossRef]

22. Rai, V.; Tandon, P.K.; Khatoon, S. Effect of chromium on antioxidant potential of Catharanthus roseus varieties and production of their anticancer alkaloids: Vincristine and vinblastine. Biomed. Res. Int. 2014, 2014, 934182. [CrossRef] [PubMed]

23. Ma, J.; Lv, C.; Xu, M.; Chen, G.; Lv, C.; Gao, Z. Photosynthesis performance, antioxidant enzymes, and ultrastructural analyses of rice seedlings under chromium stress. Environ. Sci. Pollut. Res. 2015, 23, 1768-1778. [CrossRef]

24. Bareen, E.F.; Tahira, S.A. Efficiency of seven different cultivated plant species for phytoextraction of toxic metals from tannery effluent contaminated soil using EDTA. Soil Sediment Contam. 2010, 19, 160-173. [CrossRef]

25. Premaratne, S.; Premalal, G.G.C. Hybrid Napier (P. purpureum $\times$ P. americanum) var. CO-3: A resourceful fodder grass for dairy development in Sri Lanka. J. Agric. Sci. 2006, 2, 22-33.

26. Jampeetong, A.; Muenrew, J. Interactive effects of $\mathrm{NH}_{4}{ }^{+}$concentration and $\mathrm{O}_{2}$ availability on growth, morphology, and mineral allocation of hybrid Napier grass (Pennisetum purpureum $\times$ P. americanum $\mathrm{cv}$. Pakchong1). Ecol. Eng. 2016, 91, 409-418. [CrossRef]

27. Amin, H.; Arain, B.A.; Abbasi, M.S.; Amin, F.; Jahangir, T.M.; Soomro, N.U. Evaluation of chromium phyto-toxicity, phyto-tolerance, and phyto-accumulation using biofuel plants for effective phytoremediation. Int. J. Phytoremediation 2019, 14, 1-12. [CrossRef] [PubMed]

28. Mathur, S.; Kalaji, H.M.; Jajoo, A. Investigation of deleterious effects of chromium phytotoxicity and photosynthesis in wheat plant. Photosynthetica 2016, 54, 185-192. [CrossRef]

29. Raptis, S.; Gasparatos, D.; Economou-Eliopoulos, M.; Petridis, A. Chromium uptake by lettuce as affected by the application of organic matter and $\mathrm{Cr}(\mathrm{VI})$-irrigation water: Implications to the land use and water management. Chemosphere 2018, 210, 597-606. [CrossRef]

30. Dey, U.; Mondal, N.K. Ultrastructural deformation of plant cell under heavy metal stress in Gram seedlings. Cogent Environ. Sci. 2016, 2, 1-12. [CrossRef]

31. Bareen, F.; Khadija, R.; Muhammad, S.; Aisha, N. Uptake and leaching of Cu, Cd, and Cr after EDTA application in sand columns using sorghum and pearl millet. Pol. J. Environ. Stud. 2019, 28, 2065-2077. [CrossRef]

32. Ali, S.Y.; Chaudhury, S. EDTA-enhanced phytoextraction by tagetes sp. and effect on bioconcentration and translocation of heavy metals. Environ. Proc. 2016, 3, 735. [CrossRef]

33. Naseem, S.; Yasin, M.; Ahmed, A.; Faisal, M. Chromium accumulation and toxicity in corn (Zea mays L.) seedlings. Pol. J. Environ. Stud. 2015, 24, 899-904. 
34. Nagarajan, M.; Ganes, K.S. Effect of chromium on growth, biochemicals and nutrient accumulation of paddy (Oryza sativa L.). Int. Lett. Nat. Sci. 2014, 23, 63-71. [CrossRef]

35. Huffman, E.W., Jr.; Allaway, H.W. Chromium in plants: Distribution in tissues, organelles, and extracts and availability of bean leaf chromium to animals. J. Agric. Food Chem. 1973, 21, 982-986. [CrossRef]

36. Diwan, H.; Ahmad, A.; Iqbal, M. Chromium-induced alterations in photosynthesis and associated attributes in Indian mustard. J. Environ. Biol. 2012, 33, 239-244. [PubMed]

37. Saravanan, A.; Jayasree, R.; Hemavathy, R.V.; Jeevanantham, S.; Hamsini, S.; Senthil, K.P.; Yuvaraj, D. Phytoremediation of $\mathrm{Cr}(\mathrm{VI})$ ion contaminated soil using Black gram (Vigna mungo): Assessment of removal capacity. J. Environ. Chem. Eng. 2019, 7, 103052.

38. Ramana, S.; Biswas, A.K.; Singh, A.B.; Ahirwar, N.K.; Subba Rao, A. Tolerance of ornamental succulent plant crown of thorns (Euphorbia milli) to chromium and its remediation. Int. J. Phytoremediation 2014, 17, 363-368. [CrossRef] [PubMed]

39. Mganga, N.; Manoko, M.L.K.; Rulangaranga, Z.K. Classification of plants according to their heavy metal content around north mara gold mine, Tanzania: Implication for phytoremediation. Tanzan. J. Sci. 2011, 37, 109-119.

40. Usman, K.; Al-Ghouti, M.A.; Abu-Dieyeh, M.H. The assessment of cadmium, chromium, copper, and nickel tolerance and bioaccumulation by shrub plant Tetraena qataranse. Sci. Rep. 2019, 9, 5658. [CrossRef] [PubMed]

41. Paiva, L.B.; de Oliveira, J.G.; Azevedo, R.A.; Ribeiro, D.R.; da Silva, M.G.; Vitória, A.P. Ecophysiological responses of water hyacinth exposed to $\mathrm{Cr}^{3+}$ and $\mathrm{Cr}^{6+}$. Environ. Exp. Bot. 2009, 65, 403-409. [CrossRef]

42. Subrahmanyam, D. Effects of chromium toxicity on leaf photosynthetic characteristics and oxidative changes in wheat (Triticum aestivum L.). Photosynthetica 2008, 46, 339-345. [CrossRef]

43. Wyszkowski, M.; Radziemska, M. Influence of chromium (III) and (VI) on the concentration of mineral elements in oat (Avena sativa L.). Fresenius Environ. Bull. 2013, 22, 979-986.

44. Wyszkowski, M.; Radziemska, M. Effects of chromium (III and VI) on spring barley and maize biomass yield and content of nitrogenous compounds. J. Toxicol. Environ. Health A 2010, 73, 1274-1282. [CrossRef]

45. Dube, B.; Tewari, K.; Chatterjee, J.; Chatterjee, C. Excess chromium alters uptake and translocation of certain nutrients in citrullus. Chemosphere 2003, 53, 1147-1153. [CrossRef]

46. Schiavon, M.; Pilon-Smits, E.A.H.; Wirtz, M.; Hell, R.; Malagoli, M. Interactions between chromium and sulfur metabolism in Brassica juncea. J. Environ. Qual. 2008, 37, 1536-1545. [CrossRef] [PubMed]

47. Zheng, L.J.; Liu, X.M.; Lütz-Meind, U.; Peer, T. Effects of lead and EDTA-Assisted lead on biomass, lead uptake and mineral nutrients in Lespedeza chinensis and Lespedeza davidii. Water Air Soil Pollut. 2011, 220, 57-68. [CrossRef]

48. Singh, M.; Kushwaha, B.K.; Singh, S.; Kumar, V.; Singh, V.P.; Prasad, S.M. Sulphur alters chromium (VI) toxicity in Solanum melongena seedlings: Role of Sulphur assimilation and Sulphur-containing antioxidants. Plant Physiol. Biochem. 2017, 112, 183-192. [CrossRef] [PubMed]

49. Anjum, S.A.; Ashraf, U.; Khan, I.; Tanveer, M.; Ali, M.; Hussain, I.; Wang, L.C. Chromium and aluminum phytotoxicity in maize: Morpho-physiological responses and metal uptake. CLEAN-Soil Air Water 2016, 44, 1075-1084. [CrossRef]

50. Upadhyay, R.; Panda, S.K. Influence of chromium salts on increased lipid peroxidation and differential pattern in antioxidant metabolism in Pistia stratiotes L. Braz. Arch. Biol. Technol. 2010, 53, 1137-1144. [CrossRef]

51. Daud, M.K.; Mei, L.; Variath, M.T.; Ali, S.; Li, C.; Rafiq, M.T.; Zhu, S.J. Chromium (VI) uptake and tolerance potential in cotton cultivars: Effect on their root physiology, ultramorphology, and oxidative metabolism. Biomed. Res. Int. 2014, 2014, 975946. [CrossRef]

52. Khan, A.H.A.; Butt, T.A.; Mirza, C.R.; Yousaf, S.; Nawaz, I.; Iqbal, M. Combined application of selected heavy metals and EDTA reduced the growth of Petunia hybrida L. Sci. Rep. 2019, 9, 5658-5669. [CrossRef]

53. Farid, M.; Ali, S.; Rizwan, M.; Ali, Q.; Abbas, F.; Bukhari, S.A.H.; Saeed, R.; Wu, L. Citric acid assisted phytoextraction of chromium by sunflower; morpho-physiological and biochemical alterations in plants. Ecotoxicol. Environ. Saf. 2017, 145, 90-102. [CrossRef]

54. González, A. Application of the portable chlorophyll meter in wheat and barley improvement programs. Agroecología 2009, 4, 111-116.

(C) 2019 by the authors. Licensee MDPI, Basel, Switzerland. This article is an open access article distributed under the terms and conditions of the Creative Commons Attribution (CC BY) license (http://creativecommons.org/licenses/by/4.0/). 